\title{
Persepsi Mahasiswa dan Tutor Tentang Kejadian Kritis Selama Diskusi Tutorial dan Jenis-jenis Intervensi Tutor Terhadap Kejadian Tersebut
}

\author{
Amelia Dwi Fitri*, Harsono**, E Suryadi** \\ * Fakultas Kedokteran dan Ilmu-Ilmu Kesehatan Universitas Jambi \\ ** Program Studi S2 IImu Pendidikan Kedokteran Fakultas Kedokteran Universitas Gadjah Mada
}

\begin{abstract}
Background: Tutorial group discussion is one of the key features of problem based learning. The tutor-facilitated group discussion is not always work as planned. Critical incident during tutorial is one of the factors that may hinder group dynamics. Six factors hindering group dynamics (unequal participation, lack of cohesion, lack of motivation, lack of elaboration, lack of interaction, and personality problem), play role in critical incidents during tutorial. Tutor's and students' perception on critical incidents are affected by each individual point of view on the incidents. The point of view will influence intervention expected by students and actual intervention done by tutor. Tutor's capability to intervent accordingly is one of the factors needed to ensure group discussion to progress well.

Objective: The aim of this research is to identify students and tutors perception on critical incindents during tutorial and types of of intervention done by tutor to overcome these incidents.

Method: This is a mixed-method research which combines quantitative and qualitative approaches. 352 students of 4 batches and 21 tutors involved in this research. Students and tutors'perception on critical incidents were collected using questionnaire consist of 36 Likert-scale items, and 2 open-ended questions. Intervention done by tutors was further explored using focus group discussion with tutor and students, based on quantitative result.

Result and Discussion: Similar perception were found in both students and tutors regarding the factors influenced critical incidents during tutorial the most, which was unequal participation. Nevertheless, different perception was found between students and tutors on factor that hindered discussion which require tutor intervention; students precieved difficult personality, whereas tutors stated participation imbalance. The other five factors: tutor's factors, feedback, assessment, quality of scenario, logistics, and scheduling issue were found to have role in crtical incidents in tutorial. Tutor's intervention to critical incidents had been done, even so, further increament is needed.

Conclusion: Students' and tutors' perception on critical incidents were in line in term of the most frequent incidents, but differ in factor that hinder discussion the most and require tutor's intervention. There were many other factors that influenced critical incidents besides students' factors. Interventions which had been done by tutors were not adequate in order to overcome arising critical incidents.
\end{abstract}

Keyword: Perception, critical incidents, factors hindering group success, intervention, tutorial group dynamic

\section{ABSTRAK}

Latar Belakang: Diskusi tutorial merupakan salah satu ciri khas Problem Based Learning (PBL). Kegiatan kelompok yang difasilitasi oleh tutor ini tidak selalu berjalan sesuai harapan. Kejadian kritis dalam diskusi tutorial merupakan salah satu faktor yang dapat menghambat dinamika kelompok tutorial. Enam faktor penghambat kesuksesan kelompok (ketidak seimbangan dalam partisipasi, kurangnya kohesi, kurangnya motivasi, kurangnya elaborasi, kurangnya interaksi dan kepribadian yang sulit) berperan dalam terjadinya kejadian kritis selama tutorial. Persepsi mahasiswa dan tutor terhadap terjadinya suatu kejadian kritis dipengaruhi oleh cara pandang masingmasing individu dalam melihat suatu kejadian. Hal tersebut akan mempengaruhi intervensi yang diharapkan oleh

Korespondensi: dwifitriamelia@yahoo.com 
mahasiswa dan intervensi yang dilakukan oleh tutor. Kemampuan tutor dalam melakukan intervensi yang tepat merupakan salah satu faktor yang diperlukan agar diskusi kelompok dapat berjalan dengan baik.

Tujuan Penelitian: Tujuan dari penelitian ini adalah untuk mengetahui persepsi mahasiswa dan tutor tentang kejadian kritis yang terjadi selama diskusi tutorial dan jenis-jenis intervensi yang sudah dilakukan oleh tutor untuk mengatasi kejadian tersebut.

Metode Penelitian: Penelitian ini merupakan gabungan antara penelitian kuantitatif dan penelitian kualitatif. 352 orang mahasiswa yang terdiri dari empat angkatan dan 21 orang tutor terlibat dalam penelitian ini. Persepsi mahasiswa dan tutor tentang kejadian kritis diteliti dengan menggunakan kuesioner yang terdiri dari 36 pernyataan dengan skala likert dan dua pertanyaan terbuka. Intervensi yang telah dilakukan tutor dieksplorasi melalui diskusi kelompok terfokus dengan mahasiswa dan tutor dengan mengacu pada hasil dari penelitian kuantitatif.

Hasil dan Pembahasan: Pada penelitian ini didapatkan adanya persamaan persepsi antara mahasiswa dan tutor tentang faktor yang paling berperan pada terjadinya kejadian kritis dalam diskusi tutorial, yaitu faktor ketidakseimbangan dalam partisipasi. Namun dijumpai adanya perbedaan persepsi antara mahasiswa dan tutor mengenai faktor yang dianggap paling menghambat diskusi dan memerlukan intervensi tutor, mahasiswa memilih faktor kepribadian yang sulit sementara tutor memilih ketidakseimbangan partispasi. Lima faktor lain yaitu faktor tutor, umpan balik, asesmen, kualitas skenario, sarana dan prasarana serta pengaturan jadwal ditemukan berperan dalam terjadinya kejadian kritis dalam diskusi tutorial. Intervensi tutor terhadap berbagai kejadian kritis sudah dilakukan namun masih diperlukan upaya peningkatan.

Kesimpulan: Persepsi mahasiswa dan tutor terhadap kejadian kritis sama dalam hal faktor yang paling sering dialami namun berbeda dalam hal faktor yang dianggap paling menghambat diskusi dan paling memerlukan intervensi tutor. Ada banyak faktor lain yang berperan dalam terjadinya kejadian kritis selain faktor mahasiswa. Intervensi yang telah dilakukan oleh tutor belum optimal dalam mengatasi kejadian kritis yang timbul.

Kata Kunci: persepsi, kejadian kritis, faktor penghambat kesuksesan kelompok, intervensi, dinamika kelompok tutorial

\section{PENDAHULUAN}

Kegiatan diskusi tutorial merupakan salah satu metode pembelajaran Problem Based Learning (PBL). Metode pembelajaran ini dilakukan dengan penggunaan skenario yang disusun secara seksama dan dengan mengintegrasikan berbagai disiplin ilmu berdasarkan topik tertentu, tujuannya adalah untuk memotivasi proses pembelajaran mahasiswa. Kegiatan ini dilakukan dengan metode diskusi kelompok kecil mahasiswa dengan difasilitasi oleh seorang tutor., ${ }^{1,2}$

Sejak tahun 2007, Program Studi Pendidikan Dokter Universitas Jambi (PSPD UNJA) mencoba mengimplementasikan Kurikulum Berbasis Kompetensi (KBK) dengan pendekatan PBL. Metode tutorial yang digunakan merupakan adaptasi dari metode seven jump dari Maastricht University. ${ }^{3}$ Namun, kegiatan dalam diskusi kelompok tutorial ini tidak selalu berjalan sesuai harapan. Ada banyak faktor yang menyebabkan terjadinya berbagai kejadian kritis yang dapat mempengaruhi dinamika dalam kelompok tutorial baik faktor mahasiswa, faktor tutor, faktor skenario yang digunakan atau faktor eksternal lainnya seperti sarana dan prasarana penunjang proses pembelajaran serta pengaturan jadwal. ${ }^{4}$

Kejadian kritis adalah semua bentuk kejadian, pengalaman, episode, dan lain-lain yang terjadi selama diskusi tutorial yang menimbulkan efek samping yang cukup bermakna terhadap kelangsungan proses diskusi tutorial; mengubah pandangan tutor terhadap hal-hal yang menentukan keberhasilan dalam diskusi tutorial; atau mendorong tutor untuk mengubah pendekatan yang dilakukan dalam menjalankan perannya sebagai tutor. ${ }^{5}$

Ada enam faktor yang dapat menghambat kesuksesan kelompok (six potential succes inhibitors). Faktor tersebut adalah kurangnya elaborasi, kurangnya motivasi, kurangnya kohesi, kurangnya interaksi, kepribadian yang sulit dan ketidakseimbangan dalam partisipasi. ${ }^{6} \mathrm{Gij} \&$ 
Schmidt dalam Nieminen, et al mengemukakan teori tentang faktor- faktor yang mempengaruhi keefektifan suatu kelompok tutorial. Hipotesis dari model ini adalah pengetahuan mahasiswa sebelumnya, kualitas skenario dan kinerja tutor akan mempengaruhi jumlah waktu belajar mandiri mahasiswa dan dinamika kelompok yang selanjutnya akan mempengaruhi hasil studi mahasiswa dan rasa tertarik terhadap ilmu yang dipelajari. ${ }^{?}$

Zanolli menyatakan bahwa selain faktor mahasiswa, ada banyak faktor yang dapat mempengaruhi terjadinya kejadian kritis dalam diskusi tutorial. Faktor tersebut antara lain faktor tutor, kualitas umpan balik, sistem asesmen, kualitas skenario, sarana prasarana, dan juga pengaturan jadwal ${ }^{4}$. De Grave et $a^{1}$ telah mengembangkan kuesioner dengan menggunakan enam faktor yang disebutkan oleh Dolmans et al ${ }^{6}$ kedalam 36 situasi kritis yang dapat terjadi dalam diskusi tutorial. Mahasiswa diminta menuliskan persepsi mereka tentang kejadian kritis dalam hal pengalaman terhadap suatu kejadian kritis, hambatan kejadian tersebut terhadap dinamika kelompok dan harapan terhadap intervensi tutor. Faktor ketidakseimbangan dalam partisipasi merupakan faktor yang paling sering dialami, namun faktor yang dianggap paling menghambat diskusi dan sangat memerlukan intervensi tutor adalah pada faktor kurangnya motivasi. ${ }^{6}$

Setiap kejadian kritis yang terjadi harus diatasi secara efektif dan efisien. Tutor sebaiknya tidak membiarkan hal tersebut terjadi dan berharap mahasiswa dapat mengatasinya sendiri. Tutor harus segera melakukan intervensi agar kejadian tersebut tidak sampai mengganggu dinamika kelompok. Intervensi yang dilakukan sebaiknya melibatkan mahasiswa. Apabila tutor dan kelompok tidak dapat mengatasi masalah tersebut, maka tutor dapat meminta pertolongan pihak lain, seperti dosen pembimbing akademik atau tim blok. ${ }^{8}$ Dalam melakukan intervensi, seorang tutor harus memahami tentang lima tahapan perkembangan dalam kelompok. Tahapan yang dimaksud adalah forming, storming, norming, performing dan adjourning. Kelompok paling sering mengalami konflik pada tahapan storming dan dapat mencapai kondisi kerja sama yang optimal pada tahap performing. 9

Kelompok adalah suatu unit sosial atau kesatuan sosial yang terdiri atas dua atau lebih individu yang telah mengadakan interaksi sosial yang cukup intensif dan teratur, sehingga di antara individu tersebut sudah terdapat pembagian tugas, struktur, dan norma-norma tertentu yang khas bagi kelompok tersebut. ${ }^{10}$ Kelompok juga dapat diartikan sebagai satu unit sosial yang terdiri dari dua atau lebih individu berinteraksi secara langsung, di mana masing-masing peduli dengan hubungannya dalam sebuah kelompok, peduli dengan orang lain yang menjadi anggota kelompok, dan peduli dengan ketergantungan positif mereka sehingga mereka dapat berusaha mencapai tujuan bersama. ${ }^{11}$

Berdasarkan perkembangan dalam kelompok, Schwarz telah mengemukakan suatu model intervensi yaitu Schwarz's diagnosis intervention cycle. Dalam teori ini, siklus dimulai ketika tutor melihat suatu kejadian dalam diskusi kelompok yang dapat mengganggu dinamika kelompok. Kemudian tutor membuat asumsi tentang penyebab terjadinya kejadian tersebut dan menentukan apakah akan membiarkan saja atau melakukan intervensi. Bila tutor memutuskan untuk melakukan intervensi, maka tutor harus mengkomunikasikan hal tersebut pada mahasiswa dalam kelompok dan membuat kesepakatan tentang intervensi yang harus dilakukan. ${ }^{9}$

Tujuan penelitian ini adalah untuk mengetahui persepsi mahasiswa dan tutor tentang kejadian kritis yang dapat mengganggu dinamika kelompok dalam diskusi tutorial serta intervensi yang telah dilakukan oleh tutor untuk mengatasi kejadian tersebut.

\section{METODE}

Penelitian ini merupakan gabungan antara penelitian kuantitatif dan penelitian kualitatif. 352 orang mahasiswa yang terdiri dari empat angkatan dan 21 orang tutor terlibat dalam penelitian ini. Persepsi mahasiswa dan tutor tentang kejadian kritis diteliti dengan menggunakan kuesioner dari penelitian de Grave et $a l^{9}$ yang terdiri dari 36 situasi kritis yang diukur dengan lima skala Likert dan dua pertanyaan terbuka.

Kuesioner yang digunakan telah diterjemahkan dalam bahasa Indonesia dengan metode back translation namun dengan penekanan pada tujuan menghasilkan kuesioner dalam bahasa Indonesia yang ekuivalen dengan kuesioner asli. ${ }^{12}$ Sebelum digunakan dalam penelitian, peneliti melakukan uji coba kuesioner kepada 30 orang terdiri dari mahasiswa dan tutor dengan menggunakan 
metode proportionate stratified random sampling. Validitas konstruksi diukur dengan menggunakan teknik korelasi Pearson Product Momment, dengan metode ini suatu butir dalam kuesioner dianggap valid apabila memiliki nilai r hitung > r tabel. Untuk jumlah peserta uji coba 30 orang dengan taraf signifikansi 0,05\% maka nilai r tabel yang dipakai adalah 0,361. Reliabilitas setiap butir kuesioner diukur dengan melihat nilai Alfa Cronbach dari setiap butir dalam kuesioner.

Intervensi yang dilakukan tutor dieksplorasi melalui diskusi kelompok terfokus dengan mahasiswa dan tutor dengan mengacu pada hasil dari penelitian kuantitatif. Analisis data dilakukan terhadap 322 orang mahasiswa (respon rate $100 \%$ ), terdiri dari 80 orang mahasiswa lakilaki dan 242 mahasiswi dan 21 orang tutor (respon rate $91,3 \%$ ) terdiri dari 6 orang tutor laki-laki dan 15 orang tutor perempuan.

\section{HASIL DAN PEMBAHASAN}

Berdasarkan analisis data pertama dari kuesioner, kejadian kritis yang paling sering dialami menurut persepsi mahasiswa adalah ketidakseimbangan partisipasi dan kurangnya elaborasi, namun faktor yang dianggap paling menghambat dinamika kelompok adalah kepribadian yang sulit, baru kemudian ketidakseimbangan partisipasi. Hal yang sama juga ditemukan pada harapan terhadap intervensi tutor. Menurut persepsi mahasiswa yang paling diperlukan adalah pada faktor kepribadian yang sulit.

Selanjutnya, tabel 2 menunjukkan bahwa kejadian kritis yang paling sering dialami menurut persepsi tutor ditemukan sama persis dengan persepsi mahasiswa yaitu adalah ketidakseimbangan dalam partisipasi dan kurangnya elaborasi. Namun menurut tutor faktor yang dianggap paling menghambat dinamika kelompok adalah ketidakseimbangan dalam partisipasi dan kurangnya motivasi. Sedangkan dalam hal intervensi, menurut tutor yang paling diperlukan adalah pada faktor kurangnya partisipasi.

Tabel 1. Nilai rata-rata (M) setiap komponen persepsi mahasiswa terhadap kejadian kritis selama diskusi tutorial (skala1-5) dan Standar Deviasi (SD); $(n=322)$

\begin{tabular}{lcccccc} 
Faktor penghambat & $\begin{array}{c}\text { Pengalaman } \\
\text { terhadap suatu } \\
\text { kesuksesan kelompok }\end{array}$ & \multicolumn{3}{c}{$\begin{array}{c}\text { Pengaruh kejadian } \\
\text { kritis terhadap } \\
\text { dinamika } \\
\text { kelomp }\end{array}$} & $\begin{array}{c}\text { Harapan terhadap } \\
\text { intervensi tutor }\end{array}$ \\
\cline { 2 - 8 } & $\mathbf{M}$ & $\mathbf{S D}$ & $\mathbf{M}$ & $\mathbf{S D}$ & $\mathbf{M}$ & SD \\
Ketidakseimbangan partisipasi & 3,67 & 0,69 & 3,75 & 0,56 & 3,54 & 0,73 \\
Kurangnya kohesi & 3,28 & 0,68 & 3,30 & 0,69 & 3,48 & 0,72 \\
Kurangnya motivasi & 3,23 & 0,73 & 3,58 & 0,64 & 3,65 & 0,68 \\
Kurangnya interaksi & 3,04 & 0,78 & 3,71 & 0,52 & 3,69 & 0,60 \\
Kurangnya elaborasi & 3,39 & 0,70 & 3,61 & 0,57 & 3,72 & 0,62 \\
Kepribadian yang sulit & 2,97 & 0,88 & 3,91 & 0,62 & 3,75 & 0,66 \\
\hline
\end{tabular}


Tabel 2. Nilai rata-rata (M) persepsi tutor terhadap kejadian kritis selama diskusi tutorial (skala1-5) dan Standar Deviasi (SD); $(n=21)$

\begin{tabular}{lcccccc}
\multicolumn{1}{c}{$\begin{array}{c}\text { Faktor penghambat } \\
\text { kesuksesan kelompok }\end{array}$} & $\begin{array}{c}\text { Pengalaman } \\
\text { terhadap suatu } \\
\text { kejadian kritis }\end{array}$ & $\begin{array}{c}\text { Pengaruh kejadian } \\
\text { kritis terhadap } \\
\text { dinamika kelompok }\end{array}$ & $\begin{array}{c}\text { Harapan terhadap } \\
\text { intervensi tutor }\end{array}$ \\
\cline { 2 - 8 } & $\mathbf{M}$ & SD & M & SD & M & SD \\
Ketidakseimbangan & 2,90 & 0,61 & 4,00 & 0,46 & 4,06 & 0,70 \\
partisipasi & 1,98 & 0,45 & 3,44 & 0,41 & 3,50 & 0,67 \\
Kurangnya kohesi & 2,38 & 0,79 & 3,76 & 0,68 & 3,80 & 0,67 \\
Kurangnya motivasi & 1,95 & 0,47 & 3,69 & 0,64 & 3,58 & 0,67 \\
kurangnya interaksi & 2,69 & 0,75 & 3,61 & 0,78 & 3,61 & 0,90 \\
Kurangnya elaborasi & 1,90 & 0,46 & 3,68 & 0,56 & 3,69 & 0,67 \\
Kcpribadian yang sulit & & & & & &
\end{tabular}

Peneliti juga mencoba melakukan analisis persepsi mahasiswa terhadap kejadian kritis selama diskusi tutorial berdasarkan level angkatan. Seperti tampak pada tabel 3, hasilnya menunjukkan bahwa keempat angkatan mahasiswa memiliki persepsi yang sama mengenai kejadian kritis yang paling sering mereka alami selama diskusi tutorial, yaitu ketidakseimbangan dalam partisipasi. Persamaan persepsi juga ditemukan pada pendapat mereka tentang kejadian kritis yang dianggap paling menghambat dinamika kelompok yaitu pada faktor kepribadian yang sulit. Pada harapan terhadap intervensi tutor, hanya angkatan paling senior (angkatan 2007) yang berbeda persepsi, mereka menganggap yang paling memerlukan intervensi tutor adalah faktor kurangnya elaborasi, sementara tiga angkatan lain memiliki persepsi yang sama yaitu pada faktor kepribadian yang sulit.
Analisis kedua dilakukan terhadap pertanyaan terbuka dalam kuesioner tentang enam besar kejadian kritis yang paling sering dialami menurut persepsi mahasiswa dan tutor. Gambar 1 menunjukkan bahwa dari seluruh mahasiswa yang menjadi responden, kejadian kritis yang paling sering dialami adalah situasi dimana mahasiswa tanpa persiapan mengikuti diskusi kedua tutorial (26\%), kemudian situasi dimana ada anggota kelompok yang pendiam (23\%), situasi dimana ada anggota kelompok yang dominan (20\%), situasi dimana partisipasi dalam diskusi hanya terbatas pada beberapa orang saja (12\%), situasi dimana terdapat anggota kelompok yang menjadi parasit, yaitu mahasiswa yang tidak melakukan belajar mandiri dan hanya sibuk meminta penjelasan dari teman yang lain dan menanyakan sumber bacaan mereka (11\%), dan yang terakhir adalah situasi dimana tidak ada interaksi, beberapa mahasiswa menyampaikan informasi yang tidak relevan dengan materi diskusi, namun anggota kelompok yang lain tidak mempermasalahkan hal tersebut dan melanjutka diskusi (8\%) 


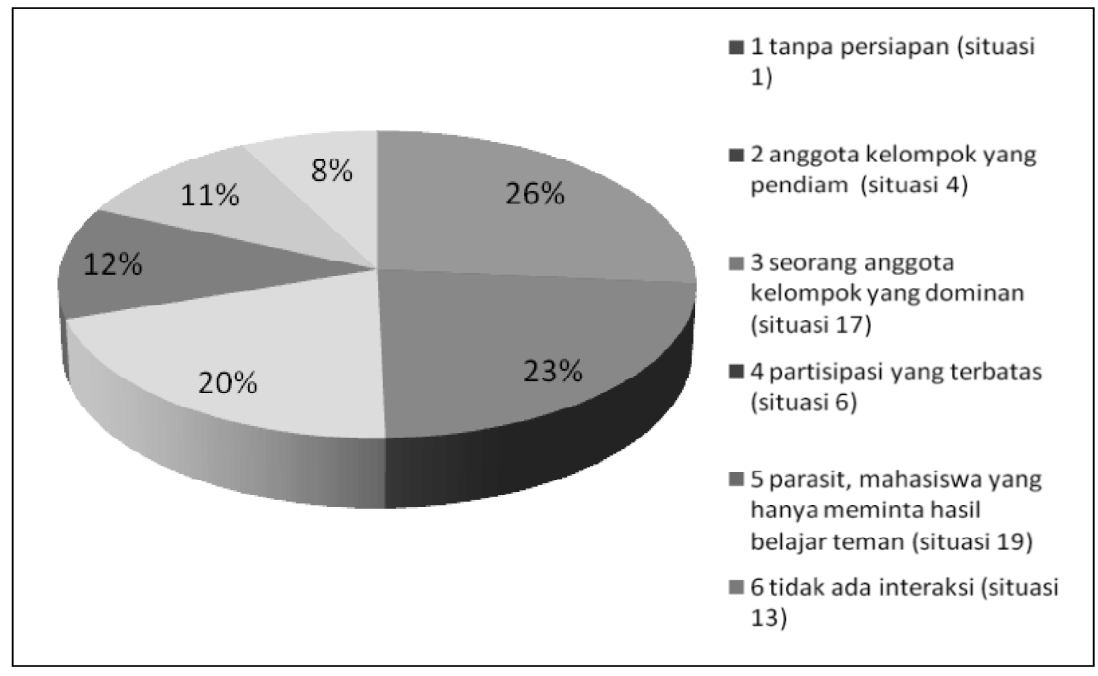

Gambar 1. Enam kejadian kritis yang paling sering dialami mahasiswa dalam diskusi tutorial (Frekuensi $=651)$ menurut persepsi mahasiswa

Selanjutnya peneliti juga melakukan analisis data enam besar kejadian kritis selama diskusi tutorial berdasarkan persepsi tutor. Gambar 2 menunjukkan enam kejadian kritis dalam tutorial yang paling sering dialami oleh mahasiswa menurut persepsi tutor adalah adanya anggota kelompok yang diam (24\%), adanya mahasiswa yang datang tanpa persiapan pada diskusi kedua (19\%), tugas yang belum dikerjakan (17\%), adanya situasi dimana pembahasan diskusi tidak mendalam (14), adanya anggota yang tampak meyakinkan (13\%) dan adanya situasi dimana mahasiswa belajar dari materi yang sama sehingga diskusi berjalan cepat dan lancar namun dangkal (13\%).

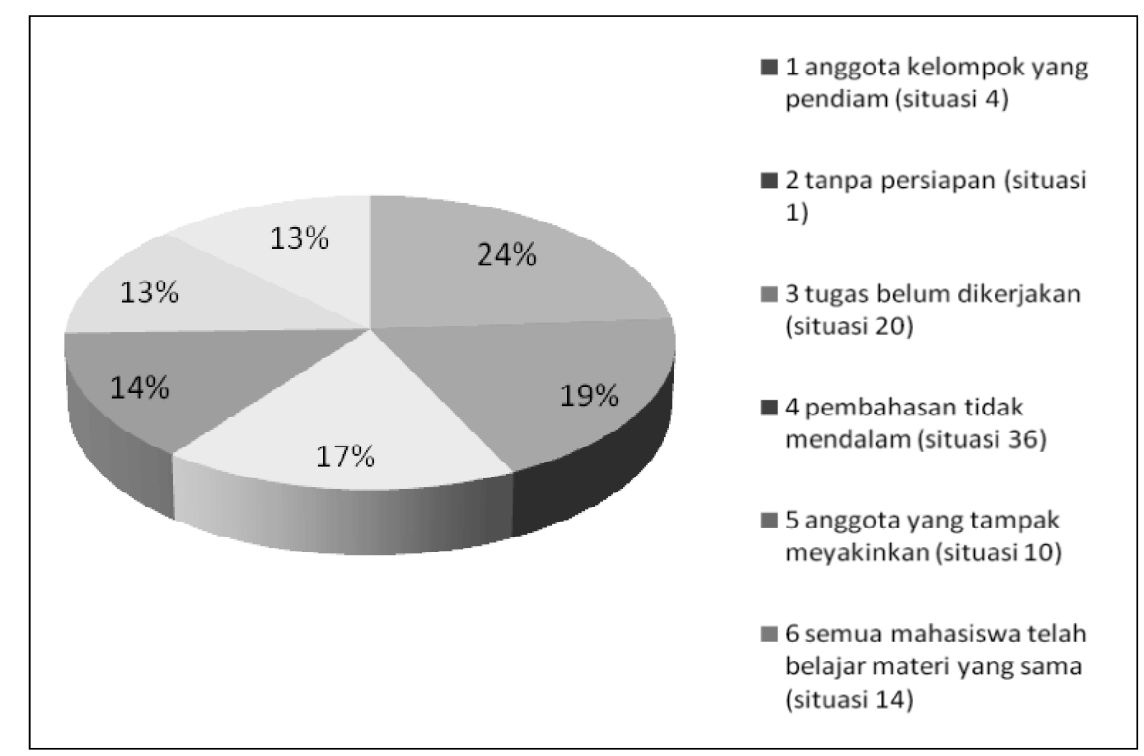

Gambar 2. Enam kejadian kritis yang paling sering dialami mahasiswa dalam diskusi tutorial (Frekuensi=63) menurut persepsi tutor 
Analisis ketiga dilakukan berdasarkan jawaban atas pertanyaan terbuka tentang pengaruh faktor lain selain faktor mahasiswa yang dapat menimbulkan kejadian kritis. Ada enam faktor yang dianalisis yaitu faktor tutor, kualitas umpan balik, sistem asesmen, kualitas skenario, sarana dan prasarana serta pengaturan jadwal.

Faktor yang paling banyak dikemukakan oleh mahasiswa adalah tutor yang yang datang terlambat. Beberapa mahasiswa menuliskan bahwa mereka harus memulai diskusi tanpa kehadiran tutor. Faktor lain dari tutor yang juga banyak ditulis mahasiswa adalah tutor yang pasif/ diam dan tidak mengarahkan mahasiswa selama diskusi. Faktor lain dari tutor yang disampaikan mahasiswa dapat dilihat pada tabel 4 .

Tabel 4. Faktor-faktor tutor yang mempengaruhi timbulnya kejadian kritis selama diskusi tutorial

No Faktor yang dianggap mahasiswa sebagai kejadian kritis

1. Tutor terlambat

2. Tutor pasif/ diam

3. Tutor tidak mengikuti sesi diskusi dari awal sampai selesai

4. Tutor mendominasi diskusi

5. Tutor acuh tak acuh, tidak memperhatikan jalannya diskusi

6. Tutor tidak datang

7. Tutor sibuk dengan HP

8. Tutor sibuk dengan urusannya sendiri (sambil mengerjakan tugas)

9. Tutor tidak menguasai skenario

10. Tutor membicarakan hal-hal yang tidak berhubungan dengan skenario

11. Tutor galak

12. Tutor hanya memperhatikan mahasiswa yang aktif

13. Tutor emosional

14. Tutor tidak up to date ilmu

15. Tutor diskusi 1 dan diskusi 2 dalam satu skenario berganti-ganti
Pada faktor kedua, ada dua kategori faktor umpan balik yang disampaikan oleh mahasiswa. Pertama menyatakan bahwa tutor tidak memberikan umpan balik selama diskusi tutorial. Kedua ada tutor yang telah memberikan umpan balik, namun dengan cara yang kurang tepat, misalnya dengan memarahi.

Pada faktor ketiga, diketahui bahwa penerapan ujian lisan di setiap akhir blok dirasakan mahasiswa memiliki banyak kelemahan. Faktor yang paling banyak dikeluhkan oleh mahasiswa adalah subjektifitas penguji. Faktor lain dapat dilihat pada tabel 5.

Tabel 5. Deskripsi persepsi mahasiswa dan tutor tentang SOCA sebagai evaluasi tutorial

No. Faktor yang dianggap mahasiswa sebagai kejadian kritis

1. Subjektifitas

2. Skenario ujian diluar skenario tutorial

3. Skenario ujian terlalu panjang, tidak sesuai dengan waktu persiapan yang disediakan

4. Tingkat kesulitan skenario masing-masing mahasiswa berbeda dikarenakan mahasiswa mendapatkan skenario yg berbeda satu sama lain

5. Standar/ kriteria penilaian tidak jelas

6. Skenario yang diujikan di luar kompetensi dokter umum

7. Penguji kelelahan

8. Penguji galak

9. Penguji bertanya di luar materi ujian

Pada faktor keempat, yang paling banyak dikeluhkan mahasiswa adalah skenario yang dirasakan terlalu luas sehingga mahasiswa bingung dalam menentukan tujuan pembelajaran. Selain itu beberapa faktor teknis seperti skenario yang berubah atau yang terlambat diberikan juga ditemukan, seperti tampak pada tabel 6 . 
Tabel 6. Faktor-faktor skenario yang dapat menimbulkan kejadian kritis dalam diskusi tutorial

No. Faktor yang dianggap kejadian kritis oleh mahasiswa

1. Skenario mengambang, membingungkan dan tidak memberikan kata kunci sehingga sulit menentukan 1.o

2. Data-data yang diberikan pada skenario tidak lengkap untuk menegakkan diagnosis

3. Skenario terlalu panjang

4. Skenario diganti atau ada perubahan pada saat tutorial

5. Skenario kurang menarik, tidak mestimulus minat belajar

6. Skenario terlalu sulit dan berbelit-belit

7. Skenario mengulang skenario lama sehingga tidak menarik untuk dibahas (mahasiswa cenderung mencontek dari kakak kelas)

8. Skenario hanya fokus pada satu penyakit saja

9. Skenario terlambat diberikan

Pada faktor kelima, tabel 7 menggambarkan bahwa sarana prasarana yang ada di PSPD UNJA belum memadai untuk menunjang kegiatan belajar mahasiswa.

Tabel 7. Faktor-faktor yang berhubungan dengan sarana dan prasarana yang dapat menimbulkan kejadian kritis dalam diskusi tutorial

No. Faktor yang dianggap kejadian kritis oleh mahasiswa

1. Fasilitas AC ruangan tutorial kurang memadai (rusak)

2. Alat tulis (spidol, penghapus) kurang memadai

3. Koneksi jaringan internet masih sulit

4. Ruangan tutor kurang memadai (sedikit dan sering tidak dibersihkan)

5. Text book di perpustakaan masih sedikit

6. Fasilitas genset kurang memadai, sering mati lampu

7. Letak perpustakaan kurang strategis (jauh di belakang gedung kuliah)
Pada tabel 8 menunjukkan faktor ke enam, yaitu pengaturan jadwal yang ternyata juga mempengaruhi timbulnya kejadian kritis menurut persepsi mahasiswa dan tutor.

Tabel 8. Faktor-faktor yang berhubungan dengan pengaturan jadwal yang dapat menimbulkan kejadian kritis dalam diskusi tutorial

\section{No. Faktor yang dianggap kejadian kritis oleh} mahasiswa

1. Jadwal sering berubah dari jadwal yang ditentukan

2. Jarak waktu antara diskusi 1 dan diskusi 2 terlalu dekat sehingga waktu belajar mandiri untuk mencari 1.O kurang

3. Jarak antara diskusi 2 dengan pleno terlalu dekat sehingga waktu untuk membuat laporan sedikit

4. Jarak antara pleno skenario terakhir dengan ujian terlalu dekat sehingga tidak fokus dalam menyelesaikan laporan tutorial

5. Jadwal terkadang berbarengan dengan jadwal tutorial yang lain

6. Pleno tidak didampingi pakar sehingga sulit menanyakan hal-hal yang ingin diketahu tentang suatu kasus dalam skenario

7. Setelah waktu tutorial diikuti jadwal kegiatan lain tanpa ada waktu belajar mandiri

8. Tutorial tentang suatu kasus dilakukan sebelum materi tentang kasus tersebut diajarkan

Analisis keempat merupakan hasil diskusi kelompok terfokus yang dilakukan pada emapat kelompok mahasiswa yang masing-msaing terdiri dari 8-10 orang dan satu kelompok tutor yang terdiri dari enam orang. Intervensi yang coba digali berpedoman pada hasil penelitian sebelumnya tentang enam besar kejadian kritis yang paling sering dialami selama diskusi tutorial menurut persepsi mahasiswa dan tutor.

Pertama, pada situasi mahasiswa tanpa persiapan, intervensi yang telah dilakukan tutor secara garis besar ada dua. Intervensi pertama dilakukan pada diskusi kedua, antara lain meminta mahasiswa mencari semua LO dan mengumpulkan pada diskusi kedua, memberi 
tugas pada mahasiswa yang datang tanpa persiapan sehingga pada diskusi kedua datang dengan persiapan, memberi daftar referensi atau jurnal yang harus dibaca dan ditanya pd diskusi kedua. Intervensi yang dilakukan pada diskusi kedua antara lain Mini lecturing dan memberikan efek jera dengan terus bertanya pada mahasiswa yang datang tanpa persiapan atau menampakkan ekspresi marah.

Kedua, pada situasi dimana terdapat mahasiswa yang $\mathrm{diam} / \mathrm{pasif}$, intervensi yang telah dilakukan tutor secara garis besar juga ada dua. Intervensi pertama adalah intervensi positif, misalnya menyarankan agar semua mahasiswa berpartisipasi, meminta mahasiswa satu persatu menjawab pertanyaan, menunjuk langsung mahasiswa pendiam untuk menyampaikan pendapatnya, atau memberikan tugas pada mahasiswa pendiam yang akan dibahas pada diskusi kedua. Intervensi negatif antara lain (dilakukan) dengan memarahi atau membanding-bandingkan mahasiswa yang pasif dengan mahasiswa yang aktif.

Ketiga, pada situasi dimana ada mahasiswa dominan, intervensi yang telah dilakukan tutor secara garis besar juga ada dua. Intervensi pertama adalah intervensi positif, misalnya dengan meminta mahasiswa lain untuk bergantian memberikan pendapat atau meminta moderator untuk mengatur agar semua mahasiswa aktif berpartisipasi. Intervensi kedua adalah intervensi negatif misalnya dengan memarahi mahasiswa dominan dengan kata-kata yang kurang enak didengar.

Keempat, pada situasi dimana partisipasi hanya terbatas pada dua orang saja. Mahasiswa lain tidak memiliki kesempatan untuk menyampaikan pendapat. Intervensi yang telah dilakukan tutor merupakan penggabungan dari intervensi terhadap mahasiswa pendiam dan dominan seperti telah disebutka di atas.

Kelima, pada situasi dimana ada mahasiswa "parasit", yaitu mahasiswa yang tidak berusaha belajar mandiri. Mahasiswa ini berusaha bertanya pada mahasiswa lain tentang hasil belajar mereka dan menanyakan sumbersumber belajar yang mereka gunakan. Intervensi yang telah dilakukan tutor masih minimal. Hal ini menurut mahasiswa antara lain disebabkan karena tutor akan sulit mengenali mahasiswa yang "parasit". Intervensi yang telah dilakukan adalah meminta mahasiswa menunjukkan sumber bacaannya, menanyakan langsung kepada mahasiswa tentang hasil belajarnya.

Keenam, intervensi yang coba digali adalah situasi dimana mahasiswa belajar dari sumber belajar yang sama. Hal ini menyebabkan pembahasan menjadi dangkal. Sebagian besar mahasiswa menyatakan hal tersebut bukan suatu kejadian kritis selama sumber bacaan yang mereka gunakan adalah sumber bacaan yang valid dan mereka dapat memahami skenario berdasarkan sumber tersebut. Namun, beberapa mahasiswa lain memiliki pendapat yang berbeda, mereka menganggap akan lebih baik bila mahasiswa belajar dari banyak sumber sehingga mereka dapat memperoleh informasi yang kaya tentang suatu topik. Hal ini dapat menerangkan bahwa faktor ini banyak dipilih oleh tutor, namun hanya sedikit dipilih oleh mahasiswa. Hal yang sama juga disampaikan oleh tutor. Berdasarkan hasil diskusi dengan mahasiswa dan tutor tersebut peneliti menyimpulkan hanya ada satu jenis intervensi yang telah dilakukan oleh tutor untuk mengatasi situasi ini. Intervensi tersebut adalah mengarahkan atau memberi saran pada mahasiswa untuk mencari sumber pembelajaran dari berbagai sumber bacaan.

Hasil utama yang didapat dari penelitian ini adalah adanya persamaan persepsi antara mahasiswa dan tutor dalam hal kejadian kritis yang paling sering dialami selama diskusi tutorial. Faktor tersebut adalah ketidakseimbangan dalam partisipasi. Situasi kejadian kritis yang termasuk dalam faktor ini antara lain adanya mahasiswa pasif (pendiam) dan mahasiswa yang datang pada diskusi kedua tutorial tanpa persiapan. Selain itu dalam penelitian ini juga ditemukan adanyan persamaan persepsi antara mahasiswa-mahasiswa berbagai angkatan tentang kejadian kritis yang paling sering dialami dalam diskusi tutorial. Mereka semua memilih faktor ketidakseimbangan dalam partisipasi, sebagai faktor yang paling sering dialami dalam diskusi tutorial.

Temuan dalam penelitian ini sama dengan temuan dalam penelitian-penelitian sebelumnya, de Grave et al $l^{9}$ menemukan faktor yang paling sering menimbulkan kejadian kritis dalam diskusi tutorial menurut persepsi mahasiswa berasal dari ketidakseimbangan dalam partisipasi. Temuan dalam penelitian ini menguatkan penelitian yang dilakukan sebelumnya oleh de Grave et al. ${ }^{9}$ Konsistensi dalam temuan ini menunjukkan bahwa 
memang ketidakseimbangan dalam partisipasi inilah yang menjadi masalah utama dalam diskusi tutorial di PSPD UNJA.

Apa yang dimaksud secara eksplisit. Pertama ketidakseimbangan dalam partisipasi ini disebabkan masih kurangnya pemahaman mahasiswa mengenai salah satu prinsip pembelajaran PBL yaitu pembelajaran sebagai proses kolaboratif. Dalam diskusi tutorial, mahasiswa didorong untuk berinteraksi satu sama lain secara seimbang. Interaksi dengan sesama anggota kelompok juga membantu mahasiswa untuk menbentuk pemahaman baru tentang suatu masalah. ${ }^{6}$

Kedua, ketidakseimbangan dalam partisipasi dapat juga disebabkan kurangnya pemahaman tutor. Tutor harus apat berfungsi sebagai fasilitator, aktivator dan stimulator. Tutor harus mampu mendorong semua anggota dalam kelompok berpartisipasi secara aktif dalam diskusi dalam mencapai tujuan pembelajaran. ${ }^{1}$

Selanjutnya pada aspek persepsi kedua dan ketiga, peneliti menemukan persepsi yang berbeda antara mahasiswa dan tutor dalam hal faktor yang dianggap sebagai penghambat utama dalam diskusi kelompok dan faktor yang paling memerlukan intervensi tutor. Meskipun faktor kepribadian sulit merupakan faktor yang paling sedikit dialami oleh mahasiswa, ternyata justru faktor ini yang menurut mahasiswa paling menghambat diskusi kelompok dan sangat memerlukan intervensi tutor. Situasi yang termasuk dalam kelompok kepribadian yang sulit antara lain adalah adanya mahasiswa dominan dalam diskusi. Situasi lain adalah mahasiswa dominan yang tidak dapat menerima kritik dari teman lain dalam kelompoknya

Sementara menurut tutor, faktor yang paling menghambat diskusi adalah ketidakseimbangan dalam partisipasi. Faktor ini juga yang dianggap paling memerlukan intervensi tutor. hal ini sama dengan pilihan mereka yang menyatakan bahwa faktor ketidakseimbangan dalam partisipasi ini yang merupakan faktor yang paling sering mereka alami dalam diskusi tutorial. Hal seperti ini juga ditemukan dalam penelitian de Grave et $\mathrm{al}^{9}$, mahasiswa paling banyak mengalami gangguan diskusi karena ketidakseimbangan partispasi. Faktor kurangnya motivasi sangat jarang mereka alami namun dianggap sebagai faktor yang paling menghambat diskusi dan sangat memerlukan intervensi tutor. Adanya perbedaan persepsi antar mahasiswa dan tutor ini juga pernah diteliti oleh Zanolli et al. ${ }^{4}$ Dalam penelitian ini didapatkan bahwa menurut mahasiwa faktor yang dapat menghambat diskusi tutorial adalah tutor yang tidak menguasai skenario. Tutor beranggapan bahwa faktor yang dapat menghambat diskusi tutorial adalah mahasiswa yang datang ke diskusi tutorial tanpa persiapan.

Penjelasan mengenai perbedaan persepsi ini peneliti dapatkan pada saat diskusi kelompok terfokus dengan mahasiswa dan tutor. Mahasiswa menganggap bahwa ketidakseimbangan dalam partisipasi memang paling sering mereka alami, namun menurut mereka hal tersebut dapat diatasi dengan mengoptimalkan peran moderator. Apabila moderator dapat berperan dengan baik, maka hal tersebut tidak akan menjadi hambatan dalam diskusi kelompok. Menurut mahasiswa, anggota yang pendiam atau datang tanpa persiapan akan lebih merugikan diri sendiri, tidak mengganggu kinerja kelompok secara keseluruhan.

Namun, faktor kepribadian yang sulit, seperti mahasiswa yang dominan, dianggap mahasiswa sangat mengganggu diskusi kelompok, meskipun jumlahnya hanya satu atau dua orang. Menurut mahasiswa disinilah peran tutor sangat dibutuhkan. Mahasiswa mengganggap moderator tidak memiliki "kuasa" untuk menegur mahasiswa yang dominan. Apabila moderator yang melakukan intervensi dikhawatirkan akan timbul kejadian kritis yang lain misalnya situasi dimana mahasiswa dominan ini tidak menerima kritik atau teguran dari moderator. Hal tersebut dapat menyebabkan situasi dalam kelompok menjadi makin buruk.

Pendapat seperti ini telah dikemukakan oleh Kindler et $a l^{5}$, dalam penelitiannya tentang kejadian kritis selama diskusi tutorial. Mahasiswa yang terlalu diam (quit) termasuk dalam kejadian kritis kategori mahasiswa secara individual (individual student category). Kategori ini meliputi kejadian-kejadian yang akan mempengaruhi kinerja kelompok secara individual namun tidak mengganggu kinerja kelompok secara keseluruhan. Mahasiswa yang dominan termasuk dalam kategori yang mempengaruhi dinamika kelompok. Kategori ini meliputi kejadiankejadian yang dilakukan oleh satu atau lebih mahasiswa atau tutor yang mengganggu kinerja kelompok secara 
keseluruhan. Sementara itu, dari hasil diskusi kelompok dengan tutor diketahui bahwa tutor mempunyai persepsi yang berbeda. Menurut tutor, jumlah mahasiswa dominan hanya sedikit, sehingga tidak akan terlalu mengganggu diskusi. Tutor mengharapkan mahasiswa dapat mengatasi sendiri mahasiswa yang dominan ini. Menurut tutor, justru mahasiswa yang pendiam atau tanpa persiapan yang akan mengganggu diskusi. Mahasiswa tidak akan mencapai tujuan pembelajaran yang diharapkan, sehingga paling memerlukan intervensi tutor.

Adanya perbedaan persepsi ini menurut peneliti harus disikapi dengan baik oleh tutor maupun oleh mahasiswa. Bila dikembalikan lagi pada definisi persepsi, maka dapat menjelaskan salah satu faktor adanya perbedaan persepsi ini. Persepsi terhadap terjadinya suatu kejadian kritis dipengaruhi oleh cara pandang masing-masing individu dalam melihat suatu kejadian. Cara pandang tersebut dipengaruhi oleh pengetahuan individu sebelumnya tentang hal-hal yang berkaitan dengan kejadian tersebut. Kejadian kritis adalah hasil interpretasi individu terhadap makna suatu kejadian. ${ }^{14}$

Mahasiswa dan tutor yang memiliki pengalaman yang berbeda terhadap situasi kritis tertentu, akan memiliki cara pandang yang berbeda pula tentang efek kejadian tersebut dalam diskusi kelompok. Harapan mereka terhadap pihak yang harus "bertanggung jawab" juga akan berbeda. Mahasiswa yang mempunyai pengalaman buruk tentang mahasiswa dominan yang tidak bisa diatasi oleh moderator, akan mengharapkan intervensi dilakukan tutor. Sementara di sisi lain ada pengalam tutor terhadap mahasiswa dominan yang ternyata bisa diatasi oleh moderator tanpa perlu intervensi tutor.

Pada analisis terhadap peranan faktor lain terhadap timbulnya kejadian kritis dalam diskusi tutorial, temuan dalam penelitian ini menguatkan teori yang dikemukakan oleh Zanolli et al. ${ }^{4}$ Menurut teori ini, selain faktor mahasiswa dan tutor, ada bebarapa faktor lain yang juga dapat mempengaruhi timbulnya kejadian kritis dalam diskusi tutorial. Faktor tersebut adalah faktor umpan balik, asesmen, kualitas skenario, sarana dan pengaturan jadwal. Pada penelitian ini ditemukan ada banyak hal dalam masing-masing faktor yang berperan dalam terjadinya kejadian kritis. Oleh karena itu, institusi selayaknya memberikan perhatian dan upaya untuk memperbaiki kelemahan-kelemahan pada masingmasing faktor sehingga proses pembelajaran bisa lebih optimal.

Pembahasan selanjutnya berhubungan dengan intervensi tutor terhadap berbagai kejadian kritis yang terjadi selama diskusi tutorial. Menurut Tuckman \& Jensen kejadian kritis dalam diskusi tutorial paling banyak terjadi pada tahap kedua dari lima tahapan perkembangan kelompok. Tahap kedua tersebut adalah "storming". Tahapan ini mempunyai karakteristik munculnya sifat individual dari anggota kelompok seperti keinginan untuk berkuasa, mengontrol dan terkadang menimbulkan frustasi. Pada tahapan ini yang dapat dilakukan oleh tutor adalah berusaha mengakomodasi semua keluhan dan kejadian dalam kelompok sehingga kelompok tetap produktif dan dapat mencapai tahapan paling optimal dari perkembangan kelompok yaitu "performing". 9

Schwarz telah mengemukakan suatu teori intervensi tutor yang disebut Schwarz's diagnosis intervention cycle. Teori ini mengemukakan bahwa tahapan pertama yang harus dilakukan oleh tutor adalah melakukan pengamatan terhadap suatu situasi yang dianggap mengganggu diskusi kelompok. Selanjutnya tutor membuat asumsi tentang alasan terjadinya situasi tersebut, kemudian memutuskan untuk melakukan intervensi atau tidak. Bila tutor telah memutuskan untuk melakukan intervensi, maka hal tersebut harus dikomunikasikan dengan anggota kelompok yang lain dan dibuat kesepakatan bersama untuk mengatasi hal tersebut. ${ }^{1}$

Hitchcock \& Anderson juga telah mengemukakan suatu model intervensi. Teori ini menekankan pentingnya menetapkan aturan-aturan yang harus dipatuhi kelompok pada awal diskusi. Bila terjadi sesuatu yang dapat mengganggu diskusi, maka tutor harus menyampaikan pada kelompok dan meminta pendapat mereka. Tutor bersama kelompok merujuk pada aturan-aturan yang telah ditetapkan di awal diskusi. Bila masalah belum teratasi maka sebaiknya tutor dan kelompok meminta bantuan pihak lain untuk mengatasinya, misalnya meminta mahasiswa yang "bermasalah" untuk menemui dosen pembimbing akademiknya di luar jadwal tutorial. ${ }^{8}$

Dari kedua teori diatas peneliti mengambil kesimpulan bahwa salah satu aspek penting dalam melakukan intervensi adalah keterlibatan mahasiswa dalam 
kelompok itu sendiri. Dengan demikian akan dicapai persamaan persepsi mengapa suatu hal terjadi, apakah suatu kejadian menghambat diskusi dan memerlukan intervensi ketua kelompok, tutor atau pihak-pihak lain. Jadi, intervensi menjadi lebih efektif bila diketahui latar belakang penyebabnya.

Berdasarkan analisis hasil penelitian, para tutor PSPD UNJA sudah melakukan intervensi terhadap berbagai kejadian kritis yang terjadi dalam diskusi tutorial. Beberapa intervensi cukup efektif untuk mengatasi kejadian kritis tersebut. Namun ada juga intervensi yang kurang efektif dalam mengatasi kejadian kritis tersebut. Semua intervensi dilakukan pada saat diskusi tutorial berlangsung. Berdasarkan hasil diskusi dengan mahasiswa dan tutor, diketahui belum ada tutor yang secara khusus melakukan intervensi di luar waktu tutorial. Intervensi yang dilakukan sebagian besar belum melibatkan mahasiswa dan belum memperhatikan aspek penyebab terjadinya suatu kejadian kritis dalam tutorial.

Dari enam besar kejadian kritis dalam diskusi tutorial, menurut peneliti situasi yang perlu mendapat perhatian adalah "situasi tanpa persiapan". Situasi ini berpotensi untuk menimbulkan banyak situasi kritis lain seperti adanya mahasiswa dominan, mahasiswa pendiam, partisipasi terbatas, mahasiswa yang menjadi "parasit". Pada situasi "tanpa persiapan", beberapa mahasiswa datang ke diskusi kedua tanpa persiapan karena mereka tidak atau hanya sedikit melakukan belajar mandiri. Situasi ini berpotensi menimbulkan ketidakseimbangan dalam partisipasi. Kejadian kritis yang dapat terjadi karena situasi ini adalah munculnya mahasiswa yang pendiam dan mahasiswa yang dominan.

Ada beberapa intervensi yang telah dilakukan tutor terhadap situasi ini. Berdasarkan waktunya, ada dua intervensi yang dilakukan yaitu intervensi pada diskusi pertama dan intervensi pada diskusi kedua. Intervensi pada diskusi pertama antara lain dilakukan dengan meminta mahasiswa untuk mencari semua tujuan pembelajaran yang telah ditetapkan pada diskusi pertama. Hasil pencarian tersebut akan dikumpulkan oleh masing-masing anggota kelompok kepada tutor pada diskusi kedua. Intervensi lain adalah dengan memberikan beberapa referensi yang harus dibaca oleh mahasiswa. Mahasiswa membuat laporan hasil belajar dari referensi tersebut dan dibahas pada diskusi kedua. Jadi intervensi ini bertujuan untuk mencegah agar situasi "tanpa persiapan" tidak terjadi. Intervensi yang dilakukan pada diskusi kedua antara lain dengan memberikan tugas pada mahasiswa yang datang tanpa persiapan. Tugas tersebut akan dikumpulkan pada saat pleno. Jadi intervensi ini bertujuan agar mahasiswa tersebut tidak mengulangi lagi perbuatannya pada diskusi tutorial skenario selanjutnya.

Menurut Hitchcock \& Anderson, salah satu upaya yang dapat dilakukan pada situasi ini adalah dengan menetapkan aturan umum yang jelas di awal diskusi kedua. Tutor bersama semua anggota kelompok menetapkan aturan yang disepakati bersama. Salah satu aturan yang dapat disampaikan adalah semua anggota kelompok harus berpartisipsi secara aktif dalam diskusi untuk mencapai tujuan pembelajaran. ${ }^{8}$

Namun, berdasarkan hasil diskusi dengan mahasiswa, masalah utama yang menyebabkan situasi ini terjadi adalah faktor penurunan motivasi. Meskipun faktor ini memiliki rerata nilai yang tidak menyolok secara kuantitatif, namun menjadi masalah yang kemungkinan menjadi salah satu penyebab utama timbulnya berbagai kejadian kritis. Penurunan motivasi ini juga ditemukan sebagai salah satu faktor yang melatarbelakangi timbulnya situasi "parasit". Pada situasi ini, terdapat mahasiswa yang tidak belajar mandiri, dia lebih memilih bertanya pada mahasiswa lain tentang berbagai hal dan asal sumber yang digunakan.

Intervensi yang dilakukan sebaiknya diarahkan pada upaya peningkatan motivasi. Untuk meningkatkan motivasi internal, diperlukan peran tutor sebagai activator. Seorang tutor harus mampu memfasilitasi mahasiswa untuk menyadari pengetahuan apa saja yang sudah mereka miliki. ${ }^{15}$ Mencoba membuat mahasiswa menyadari kelemahan dan kekurangan pengetahuan mereka terhadap kasus yang ada dalam skenario. Tutor harus menstimulus mahasiswa untuk belajar mandiri, mencari tahu tentang topik yang sedang dibahas secara komprehensif. Salah satu yang diperlukan dalam hal ini adalah keterampilan tutor dalam memberi pertanyaan pancingan. Pertanyaan yang membuat mahasiswa menyadari ada beberapa hal berkaitan dengan skenario yang belum mereka ketahui. ${ }^{9}$ 
Selain itu, Hendry et al menyatakan bahwa salah satu upaya yang dapat dilakukan untuk mendorong mahasiswa menjadi pembelajar mandiri dan memiliki kemampuan belajar yang tinggi adalah dengan memotivasi keinginan mahasiswa untuk belajar mandiri, mengoptimalkan kendali diri mahasiswa, meminimalkan kecemasan yang mungkin timbul. Faktor-faktor tersebut akan mempengaruhi keinginan belajar mandiri mahasiswa. ${ }^{16}$

Hal yang dapat dilakukan sehubungan dengan hal di atas antara lain dengan mengoptimalkan faktor-faktor yang berada disekitar mahasiswa. Faktor tersebut antara lain faktor sarana dan prasarana, faktor kualitas skenario dan faktor kinerja tutor. Sarana ruangan tutorial yang kondusif, literatur yang memadai di perpustakaan, akses internet yang baik dapat mengurangi kecemasan sekaligus meningkatkan kenyamanan dan semangat mahasiswa untuk belajar. Faktor kualitas skenario dan kinerja tutor yang baik memiliki korelasi positif dengan waktu yang digunakan oleh mahasiswa untuk belajar mandiri.?

Selanjutnya pada situasi dimana terdapat mahasiswa pendiam dan dominan, intervensi yang sudah dilakukan oleh tutor terhadap situasi ini cukup beragam. Secara umum intervensi yang dilakukan ada dua yaitu intervensi positif dan intervensi negatif. Intervensi negatif tentu saja sebaiknya dihindari. Tutor harus menjadi contoh yang baik bagi mahasiswanya (tutor as a role model). Tutor dan mahasiswa harus senantiasa saling menghargai. Menurut Schwarz salah satu intervensi yang dapat dilakukan dalam menghadapi mahasiswa yang pendiam adalah "instrumental intervention". Intervensi ini ditujukan terhadap nilai dan norma yang efeknya berkaitan dengan perilaku mahasiswa dalam kelompok yang akan mempengaruhi dinamika kelompok. ${ }^{9}$

Contoh intervensi yang dapat dilakukan adalah dengan mengajukan pertanyaan yang dapat memancing mahasiswa yang pendiam, misalnya "sejak awal diskusi, saya melihat teman kalian sudah memberikan pendapatnya tentang skenario yang kita bahas, bagaimana dengan anggota kelompok yang lain, apakah bisa ikut memberikan pendapatnya juga”. Dengan cara ini tutor dapat meminta agar semua dapat berpartisipasi aktif dalam diskusi. Cara ini dapat menyentuh mahasiswa pendiam dan secara tidak langsung menegur mahasiswa yang dominan. Tindakan lain yang dapat dilakukan adalah dengan mengoptimalkan fungsi moderator. ${ }^{9}$

Intervensi ini juga dapat dilakukan pada kondisi dimana jumlah mahasiswa dominan lebih dari satu. Hal ini tergambar dalam salah satu situasi yang ada dalam kuesioner yaitu partsipasi yang terbatas. Ada dua mahasiswa yang mendominai diskusi dan tidak memperdulikan anggota yang lain. Intervensi yang telah dilakukan oleh tutor pada dasarnya sama dengan intervensi terhadap mahasiswa dominan. Pada kondisi ini intervensi sangat diperlukan sehingga tidak terbentuk "kelompok diskusi kecil" dalam kelompok. Hal ini akan menyebabkan diskusi kelompok menjadi tidak efektif. De Grave ${ }^{1}$ menyatakan bahwa penerapan PBL yang didasarkan pada pemahaman bahwa belajar akan menjadi sangat efektif bila semua mahasiswa terlibat secara aktif di dalamnya.

\section{KESIMPULAN}

Berdasarkan hasil penelitian dan pembahasan, maka dapat diambil kesimpulan sebagai berikut:

1. Terdapat enam faktor yang mempengaruhi kesuksesan kelompok berperan dalam timbulnya kejadian kritis selama diskusi tutorial. Faktor tersebut adalah 1) ketidakseimbangan dalam patisipasi; 2) kurangnya kohesi; 3) Elaborasi yang kurang; 4) kurangnya motivasi; 5) kurangnya interaksi dan 6) kepribadian yang sulit

2. Terdapat persepsi yang sama antara mahasiswa dan tutor tentang faktor yang paling sering menimbulkan kejadian kritis selama diskusi tutorial yaitu ketidakseimbangan dalam persepsi.

3. Terdapat perbedaan persepsi antara mahasiswa dan tutor tentang faktor yang dianggap paling menghambat diskusi dan sangat memerlukan intervensi tutor. Mahasiswa mengganggap faktor yang paling menghambat diskusi adalah kepribadian yang sulit sehingga sangat memerlukan intervensi tutor.

4. Terdapat 6 faktor yang mempengaruhi timbulnya kejadian kritis dalam diskusi tutorial selain faktor mahasiswa. Faktor tersebut adalah faktor tutor, faktor kualitas umpan balik, faktor asesmen, faktor kualitas skenario, faktor sarana dan prasarana serta faktor pengaturan jadwal tutorial. 
5. Para tutor sudah berupaya melakukan berbagai intervensi untuk mengatasi berbagai kejadian kritis yang terjadi dalam diskusi tutorial namun belum sepenuhnya melibatkan mahasiswa.

6. Faktor penurunan motivasi merupakan salah satu hal yang melatarbelakangi timbulnya berbagai kejadian kritis.

Perlu dilakukan penelitian lebih lanjut mengenai hubungan antara berbagai faktor (kinerja tutor, kualitas umpan balik yang diberikan peranan faktor sarana prasarana, kualitas skenario dan pengaturan jadwal dengan timbulnya kejadian kritis dalam suatu kelompok tutorial, perlu juga dilakukan kajian lebih lanjut mengenai penyebab/latar belakang yang mendasari timbulnya berbagai kejadian kritis yang telah disebutkan dalam kuesioner penelitian.

\section{DAFTAR PUSTAKA}

1. De Grave WS, Moust J, \& Hommes J. The role of the tutor in a problem-based learning curriculum. Maastricht: Universitaire Pers Maastricht; 2003.

2. Taylor D, \& Miflin B. Problem-based learning: where are we now? Medical teacher; 2008; 30: 742-763.

3. Savin-Baden M, \& Major CH. A brief history of problem-based learning. In: Savin-Baden, M., Major, C.H. Foundations of problem-based learning. London: Open University Press; 2004: 10-22.

4. Zanolli, Henny PA, Boshuizen, De Grave. Students' and tutor perceptions of problem based learning in PBL tutorial groups at a Brazilian Medical School. Education for Health; 2002;15(2): 189-201.

5. Kindler P, Grant C, Kulla S, Pool G, \& Godolphins W. Difficult incidents and tutor interventions in problem based learning tutorials. Med Educ, 2009; 4: 866-73.

6. Dolmans DHJM, Wolfhagen HAP, \& van der Vleuten, CPM. Motivational and cognitive process influencing tutorial groups, Academic Medicine; 1998; 73(10): 22-24

7. Nieminen, K., Sauri, P., Lonka, K. On the relationship between group functioning and study success in problem-based learning. Med Educ; 2005; 40: 64-71.

8. Hitccock MA, \& Anderson AS. Dealing with dysfunctional groups, teaching and learning in medicine; 1997; 9(1): 19-24.

9. De Grave WS, Dolmans DHJM \& van der Vleuten CPM. Students perspectives on critical incidents in the tutorial group, Advance in Health Science Education; 2002; 7: 201-9.

10. Ahmadi A. Psikologi Sosial. Jakarta: Penerbit Rineka Cipta, 2007.

11. Sarwono SW, \& Meinarno, EA. Psikologi Sosial. Jakarta: Penerbit Salemba Humanika; 2009.

12. World Health Organization. Process of translation and adaptation of instruments. Available from: http:/ /www.who.int/substance_abuse/research_tools/ translation/en/ [acces April 2011], 2008

13. Nimran U. Landasan perilaku individu dan kelompok. Dalam: Nimran U. Perilaku Organisasi. Malang: Penerbit Laros; 2009; 11-30.

14. Tripp D. Critical incidents in teaching, developing personal judgement. New York: Routledge Falmer; 2006

15. Baharuddin, Wahyuni EN. Teori belajar dan pembelajaran. Yogyakarta: Arruz Media; 2010; 22-28.

16. Hendry GD, Frommer M, \& Walker RA. Constructivism and problem based learning. Journal of Further and Higher Education; 1999; 23(3): 359. 70 